\title{
Distribution, Severity, and Spread of Armillaria Root Disease in Kenya Tea Plantations
}

\author{
J. M. Onsando, Technical Manager and Plant Pathologist, Brooke Bond Kenya Limited, Kericho, Kenya; P. M. \\ Wargo, Research Plant Pathologist, Northeastern Forest Experiment Station, 51 Mill Pond Road, Hamden, CT \\ 06514; and S. W. Waudo, Plant Pathologist, Kenyatta University, P.O. Box 43844, Nairobi, Kenya
}

\begin{abstract}
Onsando, J. M., Wargo, P. M., and Waudo, S. W. 1997. Distribution, severity, and spread of Armillaria root disease in Kenya tea plantations. Plant Dis. 81:133-137.

Surveys for Armillaria root disease severity were conducted over a 5-year period in small tea farms ( 0.5 to $1.0 \mathrm{ha})$ in the 12 tea-growing districts of Kenya. The disease occurred in all tea districts, but severity was greater in the districts east of the Rift Valley. Disease severity was associated with relative amounts of residual woody debris, especially roots, from trees and shrubs present when the land was converted to tea plantations. Excavation of tea bushes in disease centers showed that infection of tea bushes occurred primarily by mycelial growth from residual tree roots and from infected tea roots rather than from rhizomorphs. Rhizomorphs were scarce, and rarely involved in infection. They were confined mostly to the surface of the residual tree roots and were found growing freely in the soil in only one tea district. Rhizomorphs were more abundant in higher elevation plantations than in lower elevation plantations, where they occurred only on residual tree roots in the deeper, cooler, moister levels of the soil. Inoculum from residual tree debris in the soil was the most important source of infection in plantations of seed origin. Secondary spread from infected tea plants to healthy ones was limited and disease centers were small. In tea plantations derived from clonal cuttings, secondary disease spread from infected to healthy tea plants was more important resulting in large disease centers or gaps due to plant death and removal. Currently, soil sanitation by thorough removal of roots of forest trees and prompt removal of infected tea bushes is the best available management practice.
\end{abstract}

Additional keyword: inoculum sources

The tea crop (Camellia spp.) is of great significance in the Kenyan economy, which is predominantly agriculture based (2). For the last 5 years, tea production and export have provided Kenya's economy with an average of over US\$220 million per year (3). Tea diseases are major limiting factors in crop performance (4), and the most important is Armillaria root disease $(10,11)$. Countrywide, yield losses from this disease have not been determined, but it is not uncommon to see losses of up to $50 \%$ of the tea bushes on many of the small tea farms (J. M. Onsando, unpublished). Crop losses on larger plantations are lower mainly because heavy machinery, used to prepare the land for planting, does a more thorough job of

Corresponding author: P. M. Wargo; E-mail:

/s=p.wargo/ou1=s24107a@mhs-fswa.attmail.com

Accepted for publication 31 October 1996.

Publication no. D-1996-1209-04R

This article is in the public domain and not copyrightable. It may be freely reprinted with customary crediting of the source. The American Phytopathological Society, 1997. removing infected residual woody debris. Removal of infected plant material results in less inoculum to initiate disease in newly established tea plantations. Also, large estates continually and promptly remove infected tea bushes and replant with new, uninfected bushes. Generally, large plantations are older and the tea bushes are derived mainly from seed-origin tea, which may be more resistant to pathogen spread than clonal tea derived from cuttings (J. M. Onsando, unpublished).

In forest situations, Armillaria spreads primarily by means of rhizomorphs or by direct mycelial growth from diseased to healthy roots. The importance of each mode of spread depends on the species of Armillaria and the forest environment (6). These processes have not been investigated in cultivated tea plantations in Kenya; therefore, this study was conducted to determine the distribution and severity of the disease and the mode of spread of the fungus, especially in small tea plantations in Kenya. A recent government program to establish tea plantations in a narrow belt along the national forests, where removal of tree stumps and roots has been inadequate and residual inoculum levels are high, makes this information even more critical.

\section{MATERIALS AND METHODS}

Disease survey. Field surveys for Armillaria root disease were conducted over a 5-year period from 1986 to 1990 in small tea farms $(0.5$ to $1.0 \mathrm{ha})$ in the 12 teagrowing districts in Kenya. The District Tea Officers, who constitute the extension staff of the Ministry of Agriculture, located small farms with tea plantations suspected of having Armillaria root disease. These farms were then visited to verify the presence of the disease. Five farms with Armillaria root disease were randomly chosen in each tea district for the survey. Each farm was approximately 1 ha in size and constituted a replication within each tea district.

On each farm, tea bushes with Armillaria root disease, as indicated by the presence of mycelial fans beneath the bark on root collars and roots, and those bushes missing in gaps putatively created by the disease, were counted. The presence of Armillaria on removed tea bushes was verified through interviews with the farmers and inspection of some recently removed plants. The survey lasted 5 years and each year constituted an independent survey (done at approximately the same time each year) in several different tea districts each year. Each district was visited only once during the 5-year period and it was possible to compare only the relative disease levels among the districts. Each farm was rated for disease severity on a scale of 1 to 10 , based on the number of dead or diseased bushes per hectare: $1=1$ to 11 bushes; $2=12$ to $22 ; 3=23$ to $33 ; 4$ $=34$ to $44 ; 5=45$ to $55 ; 6=56$ to $66 ; 7=$ 67 to $77 ; 8=78$ to $89 ; 9=90$ to 100 ; and $10=>100$. Small tea farms constitute $71 \%$ of the total tea hectarage in Kenya, with an average farm size of about 0.5 ha. Coincidentally, most of the farms surveyed were about 1.0 ha in size. So the rating of disease was a direct average of infected bushes plus vacancies due to disease per farm (equivalent to approximately 1 ha and expressed on a per hectare basis). The disease index for each tea district was derived from an average of the five farms surveyed. Significant differences in disease 
ratings among the districts were determined by analysis of variance methods and Duncan's multiple range test.

In addition to disease severity information, land use of the fields prior to conversion to tea plantations was determined by interviews or by observation. Where plantations were established on former forest land, the tree species in the nearby forests or nearby uncultivated land were identified to determine if there was a relationship between certain tree species and disease severity.

Mode of infection. In 1992, four farms in each tea district with confirmed Armillaria root disease in their tea plantations

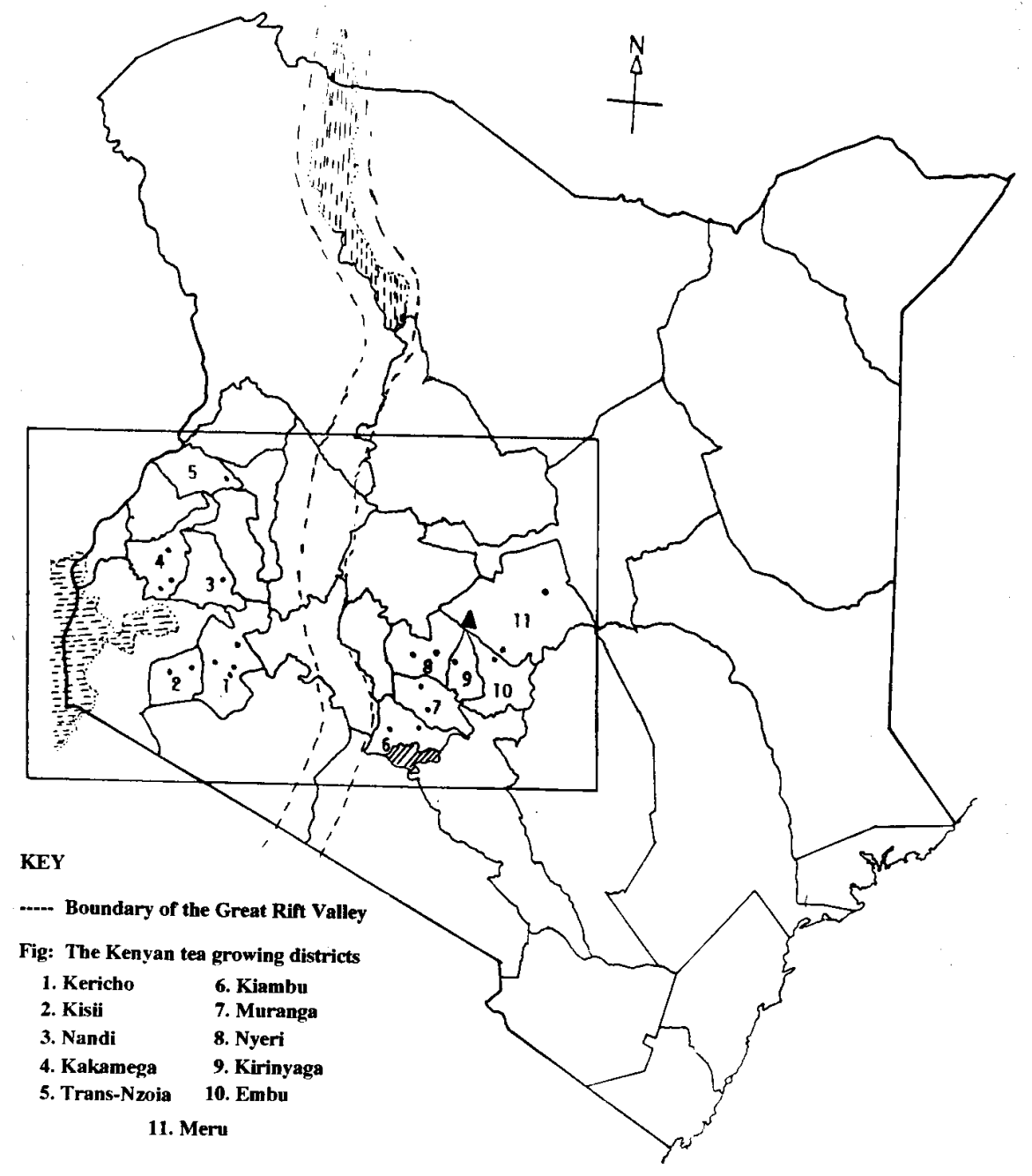

Fig. 1. Tea growing districts east and west of the Rift Valley in Kenya.

were visited and a disease center at each farm was excavated to determine the source of infection and mode of disease spread within each center. Some plantations had seed-origin plants while others were of clonal origin.

Living and dead tea bushes in each center were examined at the root collar to verify the presence of Armillaria mycelium. Root systems of at least five colonized plants were excavated and mycelial fans were traced by bark removal from the root collar downward in all colonized roots until the putative point of initial infection (contact with inoculum) was determined. The type and source of inoculum was determined as being mycelium or rhizomorphs from residual roots of the previous forest stand or from infected roots of adjacent tea plants. Rhizomorph presence and abundance on the putative inoculum source was rated visually on a scale of 0 to 3 , with 3 representing numerous, 2 representing many, 1 a few, and 0 none. It was noted if rhizomorphs were growing only in or on the inoculum source or freely in the soil. Where rhizomorphs were present and attached to roots at points of infection, it was assumed that infection occurred by mycelial growth from the rhizomorphs. In the absence of rhizomorphs, it was assumed that infection occurred by direct mycelial transfer where tea roots were in contact with the inoculum source. Where rhizomorphs did occur, it was noted if they occurred throughout the depth of the excavation or were restricted to certain levels. Soils were noted as dry or moist where rhizomorphs were present.

Also, the general architecture of the root systems of seed-origin and clonal-origin tea bushes was evaluated with reference to the orientation of the branch roots to the surface of the soil. Roots systems were described as having or not having a tap root and having branches that were oriented more vertically or horizontally from the plant base into the soil.
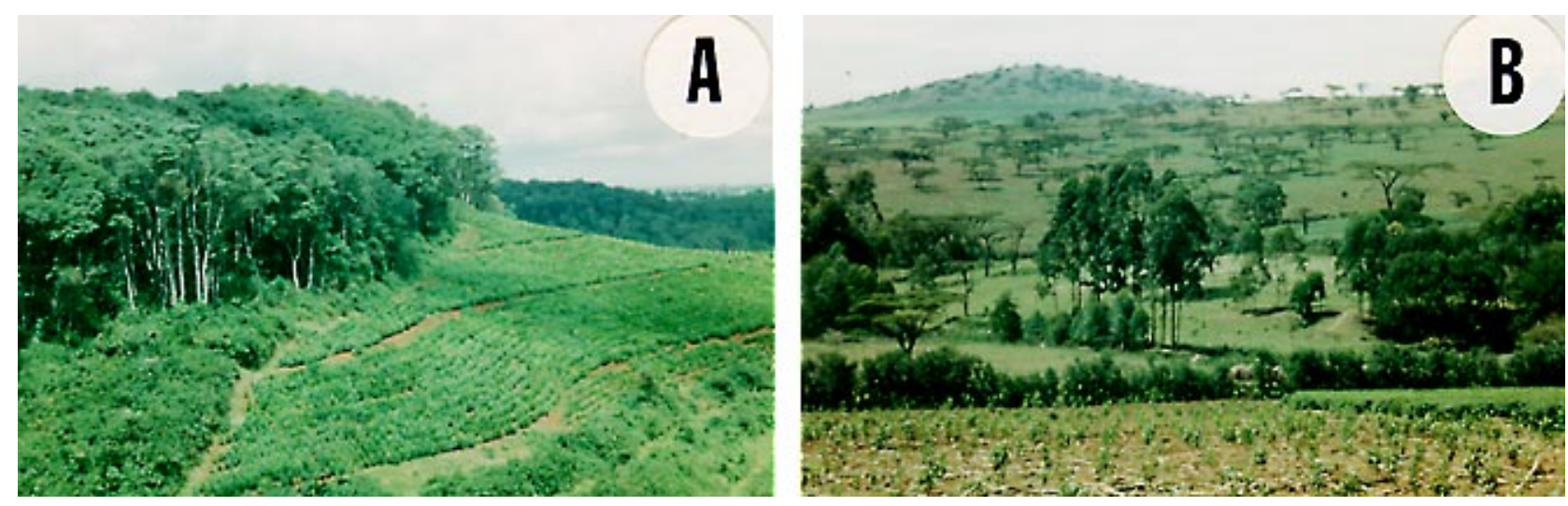

Fig. 2. (A) Forested land adjacent to these tea plantations indicates the density and diversity of the tree species removed to establish these small plantations. (B) In less densely forested areas, the flat-topped acacia, Acacia mearnsii, is the predominant species associated with Armillaria root disease (newly established tea plantation in the foreground). 


\section{RESULTS}

Distribution and disease severity. Armillaria root disease was present in all of the examined plantations in all the tea districts of Kenya but was more severe in some districts than others. Plantations in tea districts east of the Rift Valley (Meru, Embu, Kirinyaga, Nyeri, Muranga, and Kiambu) had significantly higher disease levels than those in districts west of the valley (Kitale, Kakamega, Nandi, Kericho, Myamira, and Kisii) (Fig. 1 and Table 1). There were no significant differences $(P>$ $0.05)$ in disease levels among the districts west of the Rift Valley, although plantations in Kakamega and Kisii had slightly lower levels than the rest (Table 1). In districts east of the Rift Valley, plantations in Kiambu had a significantly higher $(P<$ $0.05)$ disease rating than those in all other eastern districts and also had the highest Armillaria root disease severity in the country (Table 1).

Tea plantations with Armillaria root disease were generally those that had been established relatively recently on former forest land or on land formerly having numerous trees. In the tea districts east of the Rift Valley, plantations had been established on land previously cleared of abundant, leguminous, indigenous trees and some exotic tree species such as Acacia

Table 1. Disease severity, quantity of rhizomorphs, and observed mode of root infections on tea bushes in tea plantations in Kenya affected by Armillaria

\begin{tabular}{lccc}
\hline District & $\begin{array}{c}\text { Disease } \\
\text { severity }\end{array}$ & $\begin{array}{c}\text { Quantity } \\
\text { of rhizo- } \\
\text { morphs }^{\mathbf{y}}\end{array}$ & $\begin{array}{c}\text { Evidence } \\
\text { infection } \\
\text { by rhizo- } \\
\text { morphs }^{\mathbf{z}}\end{array}$ \\
\hline Western & & & \\
Kitale & $4 \mathrm{a}$ & 1 & ---- \\
Kakamega & $3 \mathrm{a}$ & 1 & ---- \\
Nandi & $4 \mathrm{a}$ & 1 & ---- \\
Kericho & $4 \mathrm{a}$ & 2 & ---+ \\
Nyamira & $4 \mathrm{a}$ & 1 & ---- \\
Kisii & $3 \mathrm{a}$ & 0 & ---- \\
Eastern & & & \\
Meru & $6 \mathrm{~b}$ & 0 & ---- \\
Embu & $6 \mathrm{~b}$ & 0 & ---- \\
Kirinyaga & $6 \mathrm{~b}$ & 1 & ---+ \\
Nyeri & $7 \mathrm{~b}$ & 1 & ---+ \\
Muranga & $6 \mathrm{~b}$ & 1 & ---+ \\
Kiambu & $10 \mathrm{c}$ & 2 & --++ \\
\hline
\end{tabular}

${ }^{x}$ Disease severity index, 1 to 10 based on number of dead or removed plants per hectare where $1=1$ to 11 and $10=>100$ in Armillaria disease centers (average of 5 farms per district). Means followed by same letter are not significantly $(P=0.05)$ different from each other according to Duncan's multiple range test $(\mathrm{n}=5)$.

${ }^{\mathrm{y}}$ Presence and quantity of rhizomorphs was visually rated as $0=$ none, $1=$ few, $2=$ several, and $3=$ many.

${ }^{\mathrm{z}}$ Each - or + represents an excavation of a single disease center in each of four farms in each tea district; at least 5 tea plants were excavated in each disease center. A - also indicates that infection occurred by root contact. saligna (Labill.) H. L. Wend., Acacia mearnsii De Wild., and Grevillea robusta Cunn (Fig. 2A). The association of Armillaria root disease severity and former forest land was linked to the abundance of forest trees, but not to any one species. A similar association of Armillaria root disease and plantations established on land formerly inhabited by trees was observed in the districts west of the valley. Much of this land, especially at lower elevations was savannah with widely dispersed trees (Fig. 2B). The most common tree species in this area was A. mearnsii, the flat-topped acacia, and many disease centers were associated with stumps of this species (Fig. 2B). Dis- ease was minimal or absent in tea plantations that were established on former arable land.

Mode of infection and spread. Excavation of diseased tea bushes showed that most infections occurred by direct mycelial growth from the inoculum source, either residual tree roots or infected tea roots, to healthy tea roots (Table 1). On diseased plants in plantations of seed origin, most infections were observed to originate from contacts with inoculum in residual tree roots. Secondary disease spread from infected tea bushes to healthy ones was limited and disease centers were confined to individual or several plants (Fig. 3B). Most
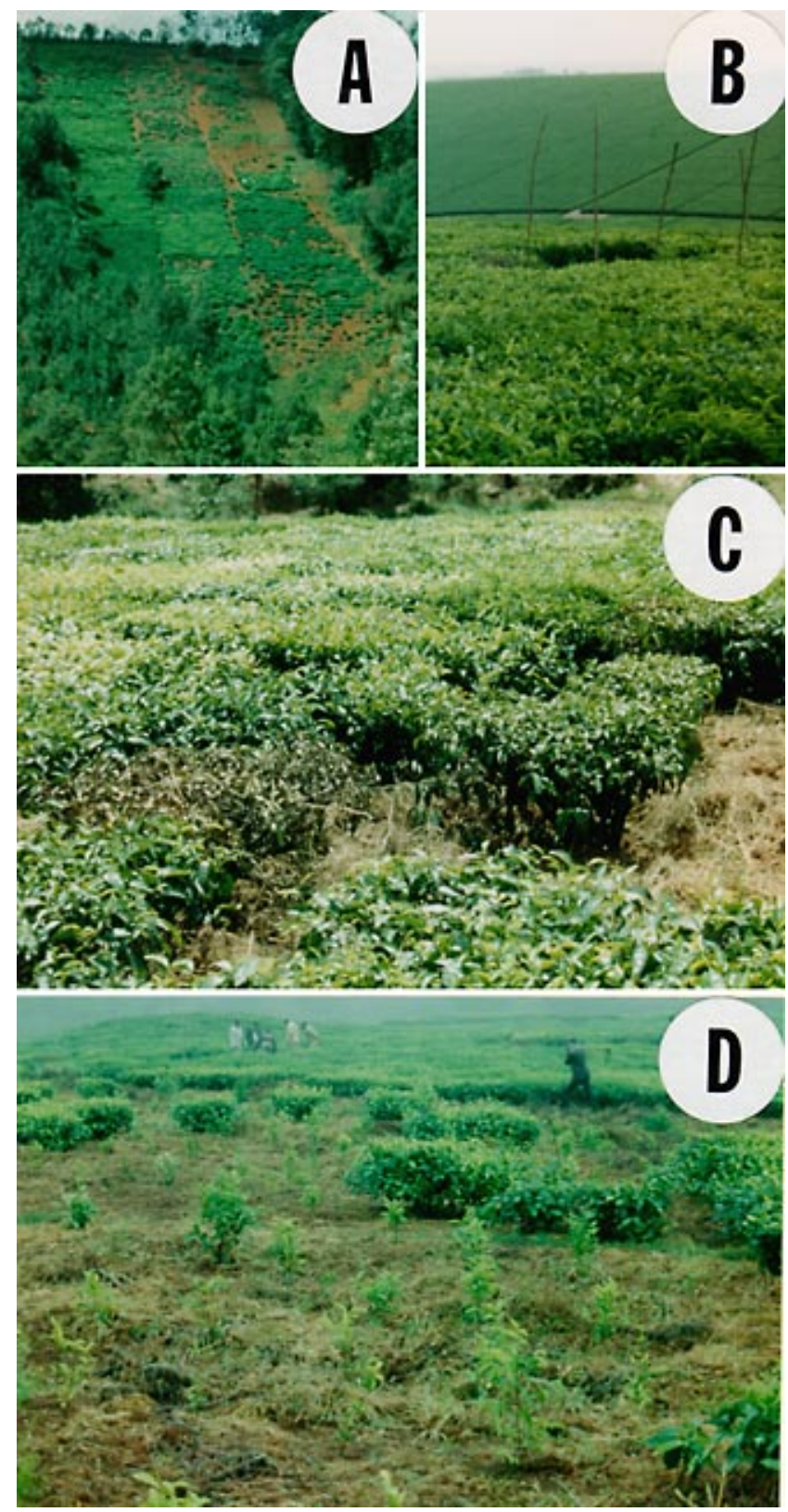

Fig. 3. (A) Young, small tea plantation showing losses of tea bushes from Armillaria root disease. (B) Older, large tea plantation showing limited losses of tea bushes from Armillaria root disease. A disease gap is delineated by wood stakes in the foreground. (C) Disease gap forming in a small tea plantation; some infected and killed plants have been removed. (D) Clonal origin plantation with a large disease center (foreground) formed by spread from secondary inoculum from infected tea bushes. Most killed plants have been removed and replaced with young seedlings. 
infections observed in plantations of clonal tea (derived from cuttings) originated from contacts with inoculum from infected adjacent tea bushes and secondary spread resulted in large patches (gaps) of dead and dying plants (Fig. 3A,C,D). In these clonal tea plantations, plants infected initially from residual tree inoculum usually had long since been removed and, in many cases, replaced with seedlings (Fig. 3D). In small disease centers where all colonized dead plants still remained, initial disease establishment was traced to root contact with inoculum from residual tree roots.

Rooting habit in seed-origin tea plants was different from that of clonal tea plants derived from rooted cuttings (Fig. 4). Plants originating from seed had a prominent, deep-penetrating tap root with lateral branches that grew downward more verti-
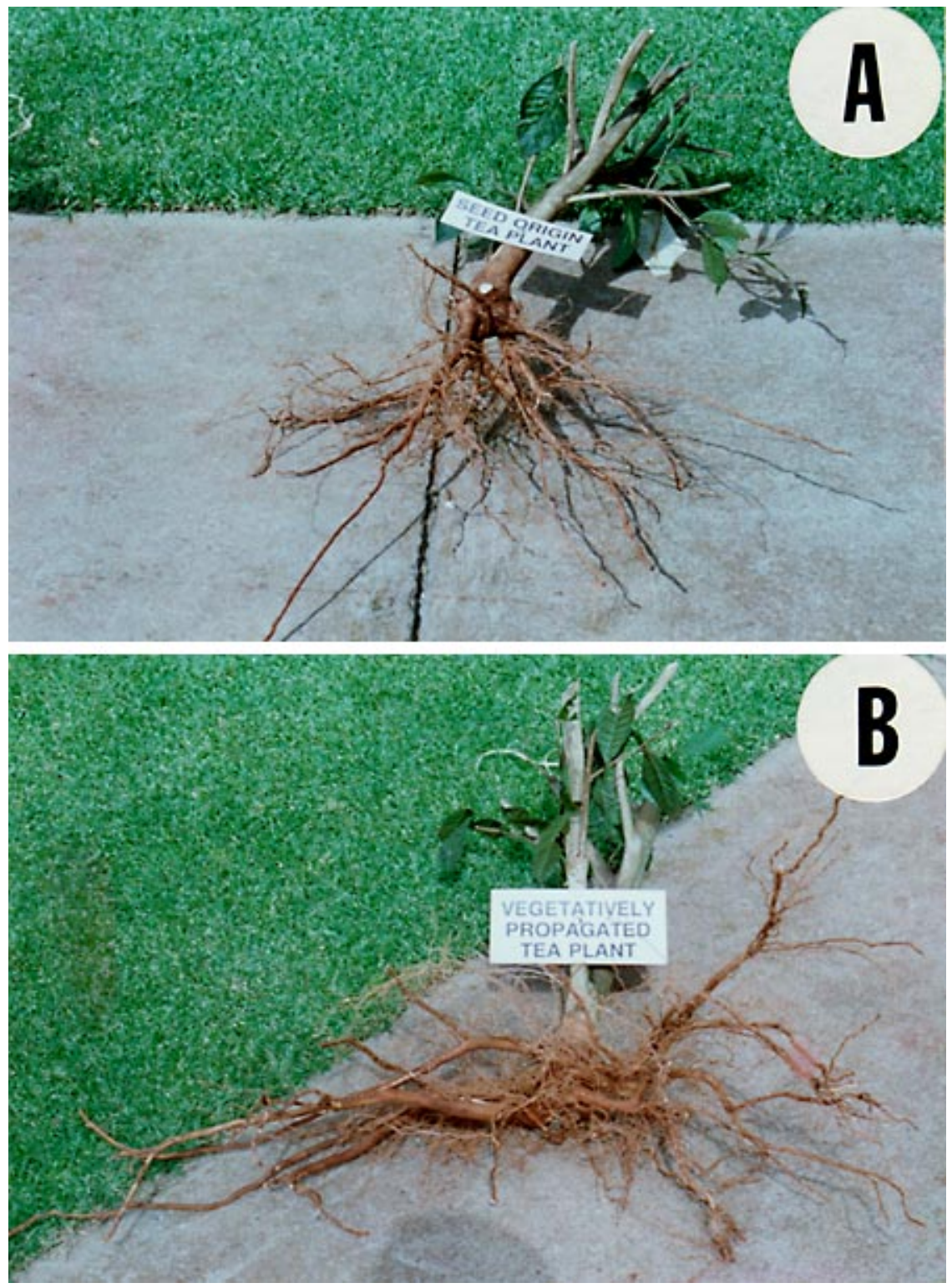

Fig. 4. Root architecture. (A) Seed-origin tea bush showing a prominent tap root and more vertically oriented root system. (B) Clonal tea bush of vegetative origin showing lack of a tap root and a more horizontally oriented root system. cally to the soil surface. The root systems of plants derived from cuttings lacked a tap root. Some branch roots also grew downward at an angle but most grew horizontally from the root/stem base. This horizontal root architecture enhanced root contacts between plants and apparently facilitated secondary spread of Armillaria root disease.

Rhizomorph occurrence. Rhizomorphs were found in tea plantations in five of the six western and four of the six eastern tea districts; plantations in seven of the districts were rated as having only a few rhizomorphs (Table 1). Rhizomorphs occurred most numerously in plantations in the higher elevation districts of Kericho and Kiambu. Rhizomorphs were found growing freely in the soil only in the Kericho district; branching appeared to be mainly monopodal. In all other districts, rhizomorphs were found growing only on the surface of residual tree roots from the previous woody vegetation. Few rhizomorphs were found growing on the bark surface of living roots of tea bushes. In the lower elevation sites, rhizomorphs, if they occurred, were only on woody debris that was in the deeper, cooler, moister levels of the soil.

\section{DISCUSSION}

Armillaria root disease was present in all the tea-growing districts of Kenya, but its severity varied from district to district. Differences in disease levels among the districts may be associated with differences in the amounts of woody debris, especially roots, that are left in the soil after tree removal prior to plantation establishment and that serve as inoculum sources. The abundance of inoculum in residual woody debris in the soil was not documented in this study, but we did observe an association of higher disease in plantations established on former forest land. Plantations east of the Rift Valley were established in areas that prior to conversion had denser forests with more tree species, compared with plantations established west of the valley, an area that is more savannah-like with scattered trees on the landscape. In contrast to both of these two situations was the very limited occurrence of Armillaria root disease in tea plantations established on former arable land, which probably lacked any woody debris in the soil.

Disease establishment occurred through infections of healthy tea roots in contact with colonized residual tree roots of the former forest. Infections occurred predominantly by direct mycelial growth from the colonized residual roots to healthy tea roots rather than by rhizomorphs growing from the residual woody roots. Although rhizomorphs were present on residual woody roots in most of the tea growing districts of Kenya, they were few in number and had a minor role in the epidemiology of Armillaria root disease of tea. Rhizomorphs were abundant in both the soil and on root tissues only in the Kericho district, where plantations are at elevations of 2,000 $\mathrm{m}$ and above. In the low elevation districts, which tend to be hotter and drier, rhizomorphs occurred only on residual tree roots in the deeper, cooler, moister levels of the soil, suggesting that temperature and moisture are major limiting factors to rhizomorph production. Gadd (5) reported that rhizomorph production in nature was rare in Nyasaland on tea and on cocoa in the Gold Coast. Rishbeth (15) and Swift (16) also observed that rhizomorphs were scarce or absent in some areas of the tropics. This is in contrast to temperate regions, where rhizomorphs are more abundant and have a major role in infection and spread of most Armillaria spp. $(8,14)$.

Rhizomorph production varies among Armillaria spp. (14) and this could be an 
important factor in the distribution of rhizomorphs observed in this study. The species causing disease in the plantations surveyed is unknown presently. Two Armillaria spp. have been identified tentatively in Kenya, A. heimii Pegler (= A. fuscipes Petch) and A. mellea (Vahl:Fr.) P. Kumm. $(12,13,17)$ and some isolates from tea plantations in Kenya were identified tentatively to one group of $A$. heimii sensu lato (7). The distributions of these two species are not completely known, and other species may be present as well (7). A. mellea commonly produces rhizomorphs in nature and these are dichotomously branched. A. heimii produces thick, fast-growing ropelike rhizomorphs in culture that are typically monopodal (C. Mohammed, University of Tasmania, personal communication). Rhizomorph branching was observed in only one district and these rhizomorphs had monopodal branches. Other studies on Armillaria isolates from forested regions of Kenya, some near areas of tea plantations, failed to identify Armillaria to species but did show that at least three distinct groups existed, based on morphological and isozyme characteristics (9).

Differences in disease severity among plantations were also related to secondary disease spread, which was associated with differences in the rooting habits of seedorigin and clonal-origin tea plants. Seedorigin tea bushes had well-developed tap roots and branch roots that were oriented more vertically in the soil. Excavations of seed-origin plants showed that root contacts between adjacent plants occurred less frequently and deeper in the soil and consequently at a greater distance from the root-stem base. Colonization of the rootstem base is important in disease and symptom development within an individual plant and spread to adjacent ones (10). In contrast, clonal tea plants had no prominent tap root and many branch roots were oriented more horizontally in the soil, thus providing for earlier and more frequent contact with roots of adjacent plants closer to the root-stem base.

Disease establishment from colonized residual tree roots, secondary spread by root-to-root contact of infected to healthy plants, and the limited involvement of rhizomorphs in the infection and spread processes in tea plantations, indicate that adequate removal of woody debris, especially roots, prior to planting of tea seedlings, and prompt removal of infected tea plants, especially in clonal tea plantations, are significant prophylactic measures that can be used against the disease (1).

\section{ACKNOWLEDGMENTS}

We thank the U.S. Department of State, Agency for International Development, for partially funding this project. This research was conducted while the first author was the Research Pathologist for the Tea Research Foundation of Kenya located in Kericho.

\section{LITERATURE CITED}

1. Anonymous. 1986. Tea Growers Handbook. 4th ed. Tea Res. Found. Kericho, Kenya.

2. Anonymous. 1987. Tea times of the Tea Board of Kenya. No. 1: June.

3. Anonymous. 1989. Int. Tea Commit. Annu. Bull. Statist., London.

4. Carr, M. K. V. 1972. The climatic requirements of the tea plant. A review. Exp. Agric. Rev. 8:1-14.

5. Gadd, C. H. 1930. The Armillaria root disease of tea. Tea Q. 3(4):109-113.
6. Kile, G. A., McDonald, G. I., and Byler, J. W. 1991. Ecology and disease in natural forests. Pages 102-121 in: Armillaria root disease. C. G. Shaw and G. A. Kile, eds. U.S. Dept. Agric. For. Serv. Agric. Handb. 691.

7. Mohammed, C., and Guillaumin, J. J. 1992 Armillaria in tropical Africa. Pages 207-217 in: Aspects of Tropical Mycology. S. Isaac, J. C. Frankland, R. Watling, and A. J. S. Whalley, eds. Cambridge University Press, Cambridge, U.K.

8. Morrison, D. J., Williams, R. E., and Whitney, R. D. 1991. Infection, disease development, diagnosis, and detection. Pages 62-75 in: Armillaria root disease. C. G. Shaw and G. A. Kile, eds. U.S. Dept. Agric. For. Serv. Agric. Handb. 691.

9. Mwangi, L. M., Lin, D., and Hubbes, M 1989. Identification of Kenyan Armillaria isolates by cultural morphology, intersterility tests and analysis of isozyme profiles. Eur. J. For. Pathol. 19:399-406.

10. Onsando, J. M. 1986. Armillaria root rot (A. mellea), an important disease of tea Camellia sinensis in Kenya. Tea 7(1):25-28.

11. Onsando, J. M., Waudo, S. W., Magambo, M. J. S. 1989. A biological control approach to root rot of tea Armillaria mellea (Vahl:Fr) Kummer in Kenya. Tea 10(2): 165-173.

12. Pegler, D. N. 1977. A preliminary agaric flora of East Africa. Kew Bull. Addit. Ser. 6:91-94.

13. Pegler, D. N. 1986. Agaric flora of Sri Lanka Kew Bull. Addit. Ser. 12:81-86.

14. Redfern, D. B., and Filip, G. M. 1991. Inoculum and infection. Pages 48-61 in: Armillaria root disease. C. G. Shaw and G. A Kile, eds. U.S. Dept. Agric. For. Serv. Agric. Handb. 691.

15. Rishbeth, J. 1978. Effects of soil temperature and atmosphere on growth of Armillaria rhizomorphs. Trans. Br. Mycol. Soc. 70:213-220.

16. Swift, M. J. 1968. Inhibition of rhizomorph development by Armillaria mellea in Rhodesia forest soils. Trans. Br. Mycol. Soc. 51: 241-247.

17. Watling, R. 1992. Armillaria staude in the Cameron Republic. Persoonia 14:483-491. 